\title{
Seroprevalence of rubella-specific $\lg M$ and $\lg G$ antibodies among pregnant women seen in a tertiary hospital in Nigeria
}

This article was published in the following Dove Press journal:

International Journal of Women's Health

6 January 2015

Number of times this article has been viewed

Okikiola M Olajide'

Maryam Aminu'

Abdullahi J Randawa ${ }^{2}$

Daniel S Adejo 2

'Department of Microbiology, Faculty of Science, Ahmadu Bello University,

${ }^{2}$ Department of Obstetrics and

Gynaecology, Ahmadu Bello University

Teaching Hospital, Zaria, Nigeria

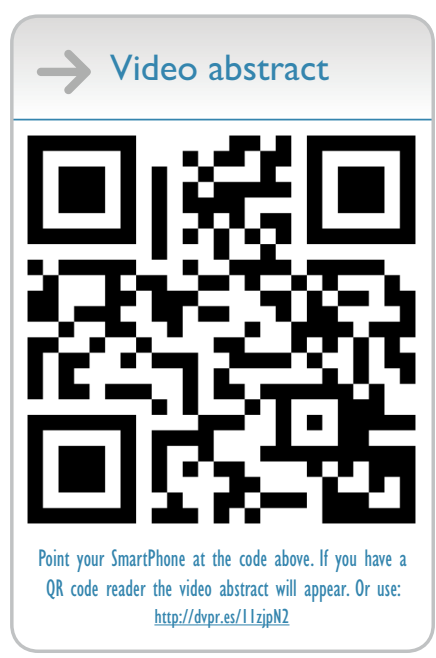

Correspondence: Maryam Aminu Department of Microbiology, Faculty of Science, Ahmadu Bello University, Zaria, Kaduna, Nigeria Tel +234803328 7031

Email maryamaminu@yahoo.com
Background: Rubella is a contagious viral infection that in pregnant women leads to the infection of a developing fetus, causing fetal death or congenital rubella syndrome.

Objective: Pregnant women are not routinely screened for rubella in Nigeria. Epidemiological data on rubella is therefore necessary to create awareness and sensitize health care administrators and providers.

Materials and methods: A cross-sectional study was carried out at Ahmadu Bello University Teaching Hospital between June and August 2012 to determine the prevalence of immunoglobulin $\mathrm{M}(\mathrm{IgM})$ and immunoglobulin $\mathrm{G}$ (IgG) antibodies to rubella virus in pregnant women using enzyme-linked immunosorbent assay kits. Seroprevalence was compared among 160 pregnant women attending the antenatal clinic of Ahmadu Bello University Teaching Hospital and 20 nonpregnant women of childbearing age studying at Ahmadu Bello University. Prior to sample collection, questionnaires were administered to the women to obtain data on sociodemographics, awareness and knowledge of rubella, possible risk factors, and clinical symptoms associated with the viral infection.

Results: Of the 160 pregnant women, 149 (93.1\%) and $62(38.8 \%)$ were positive for anti-rubella IgM and IgG antibodies, respectively. Similarly, of the 20 nonpregnant women, 18 (90\%) and eight (40\%) were positive for rubella IgG and IgM antibodies, respectively. None of the possible risk factors studied were significantly associated with infection. Age and other sociodemographic factors were of little significance, and awareness of rubella was low.

Conclusion: The prevalence of rubella was high in both pregnant (93.1\%) and nonpregnant women $(90 \%)$, suggesting sustained transmission, which further suggests endemicity. The presence of rubella IgM and IgG antibodies in pregnant women predisposes babies to congenital rubella syndrome and emphasizes the need for the initiation of a national rubella vaccination program in Nigeria.

Keywords: seroprevalence, rubella, antibodies, pregnant women, Nigeria

\section{Introduction}

Rubella, also known as German measles or 3-day measles, is a contagious viral infection caused by rubella virus, an enveloped positive-stranded ribonucleic acid virus that is a member of the family Togaviridae, ${ }^{1}$ genus Rubivirus. ${ }^{2}$ The virus causes a mild rash-like disease that is associated with low-grade fever, lymphadenopathy, and a short-lived morbilliform rash. ${ }^{3}$ Considered a relatively benign infection, rubella virus received considerably little attention after its recognition in 1881 until its association with congenital defects was recognized by an Australian ophthalmologist, N McAlister Gregg, in 1941. ${ }^{4}$

Transmitted in airborne droplets when infected people sneeze or cough, rubella is an acute, usually mild viral disease traditionally affecting susceptible children and 
young adults worldwide. ${ }^{2,5,6}$ Rubella infection just before conception and in early pregnancy may result in miscarriage, fetal death, or congenital defects known as congenital rubella syndrome (CRS), ${ }^{3,7}$ which is characterized by multiple defects, particularly to the brain, heart, eyes, and ears. The highest risk of CRS is found in countries with high rates of susceptibility to rubella among women of childbearing age, and worldwide an estimated 110,000 babies are born with CRS every year. ${ }^{7}$

There is no specific treatment for rubella, but the disease is preventable by vaccination. Although a comprehensive vaccination program in most industrialized regions, such as North America, Europe, Japan, and Australia, has reduced the incidence of the disease in these areas to low levels, vaccination is not carried out in many developing countries, ${ }^{3}$ such as Nigeria. Epidemics occur every 6-10 years, with explosive pandemics occurring every $20-25$ years. ${ }^{8}$ Epidemics in tropical countries usually pass unrecognized, due to the lack of significant clinical symptoms in affected children. ${ }^{3}$

Two specific antibodies are associated with rubella. The first to appear is immunoglobulin (Ig) M antibody, which rises and peaks 7-10 days after infection and then reduces after several weeks. The IgG antibody develops more slowly, but remains positive for life, hence conferring immunity against repeat infection. Therefore, the presence of IgM antibody indicates a recent infection, while $\mathrm{IgG}$ antibody indicates an old infection and immunity. ${ }^{9}$ Most publications on the incidence and prevalence of rubella infection conducted in Nigeria have been on either IgM or IgG, but not both. ${ }^{10-17}$ This study aimed at detecting the presence of both antirubella IgM and IgG antibodies in pregnant women attending Ahmadu Bello University Teaching Hospital (ABUTH), Zaria, thereby giving a complete picture of the occurrence of the disease among pregnant women in northern Nigeria. This study will also help to ascertain possible risk factors associated with the spread of the virus and determine the level of awareness of infection among pregnant women. More importantly, this study, combined with the findings of other studies on rubella in Nigeria, will provide information necessary for health care administrators and health care providers in Nigeria to address rubella.

\section{Materials and methods Study area and population}

The study was conducted between the months of June and August 2012 in the antenatal clinic of ABUTH, Shika, Zaria, Nigeria. ABUTH is a referral hospital that receives patients from all over Kaduna State and some neighboring states like Zamfara, Katsina, and Kano. Ethical approval for the study was obtained from the ethical committee of ABUTH. The study population comprised 160 pregnant women in different trimesters of pregnancy who expressed interest in participating in the study and gave consent. In order to compare prevalence between pregnant and nonpregnant women in the same community, determine if exposure to infection occurs more frequently before or during pregnancy, and also determine if awareness of the infection will be higher in an academic environment, 20 nonpregnant women of childbearing age studying at $\mathrm{ABU}$, Zaria, Nigeria were involved in the study.

\section{Sample collection and processing}

Prior to sample collection, structured questionnaires were administered to all the women to obtain information on medical, obstetric, and sociodemographic characteristics, and also data on possible risk factors and knowledge of rubella. Pregnant women were approached consecutively once a week for a period of 7 weeks, while nonpregnant women were approached randomly within the university female hostels for a week. Three milliliters of venous blood sample was collected from each of the women using a standard aseptic technique into properly labeled plain bottles. The blood samples were allowed to stand at room temperature to allow for blood clotting, after which samples were transported to the laboratory, centrifuged at 2,500 rpm for 5 minutes, and sera separated. Sera were stored at $-20^{\circ} \mathrm{C}$ until analysis.

\section{Analysis of samples}

Sera were analyzed for anti-rubella IgM and IgG antibodies using enzyme-linked immunosorbent assay commercial diagnostic kits (Diagnostic Automation/Cortez Diagnostics, Inc., Calabasas, CA, USA). The assays were carried out according to the manufacturer's instructions. The results were read by a microplate reader (GF M3000; B Braun Scientific and Instrument, UK) and compared in a parallel manner with the calibrator and controls. Samples were interpreted as positive if their rubella IgM or IgG index was equal to or higher than the defined rubella IgM or IgG index, which was 1 . All samples with an index of 0.90 or less were interpreted as negative, and those with an index of 0.91-0.99 were equivocal.

\section{Statistical analysis}

The data obtained from the questionnaires and the results of the laboratory analysis were entered into Microsoft Excel, analyzed using SPSS version 16, and reduced to percentiles 
and figures. The Pearson $\chi^{2}$ test at a $95 \%$ confidence interval and a significance level of 0.05 was used to determine the relationships between the data collected and prevalence rates. $P<0.05$ was considered significant.

\section{Results}

\section{Sociodemographic and reproductive characteristics}

A total of 160 pregnant and 20 nonpregnant women were enrolled in the study. The age of the pregnant women ranged from 18 to 47 years, while that of the nonpregnant women ranged from 17 to 43 years (Table 1). The mean age of the pregnant women was 27.8 years, while that of the nonpregnant women was 23.3 years. More than half of the pregnant women $(51.2 \%)$ were in their second trimester (Table 2). Reproductive characteristics, such as the number of term deliveries, preterm delivery, live births, stillbirths, spontaneous abortions, surviving children, and malformed children were studied (Table 3 ). The means of term deliveries, preterm deliveries, live births, and surviving children were 2.8 (94 of 160, minimum one, maximum eleven), 1.1 (16 of 160, minimum one, maximum two), 2.7 (92 of 160, minimum one, maximum eleven), and 2.5 (89 of 160 , minimum one, maximum eight), respectively; 33 (20.6\%), 14 (8.7\%), and four $(2.5 \%)$ of the pregnant women who had a history of spontaneous abortion, stillbirth, and malformed children, respectively. More than a quarter $(28.1 \%)$ of the pregnant women had at least five children residing with them, while even more (33.8\%) have fewer than five children living with them. Most (103 of 160) of the pregnant women were educated up to the tertiary level, and 78 of them were in an occupation that involved children (Table 4).

\section{Clinical characteristics and awareness}

Of the 160 pregnant women, 26 (16.2\%), 23 (14.4\%), five (3.1\%), and nine (5.6\%) had fever, aching joints, rash, and headache, respectively, at the time of the study. None of them had swollen lymph nodes at the back of their neck or behind their ears. Similarly, one (5\%) of the nonpregnant women had rash, headache, and swollen lymph nodes, while two $(10 \%)$ had fever and aching joints. Only $20(12.5 \%)$ and five $(25 \%)$ of the pregnant and nonpregnant women, respectively, had knowledge of rubella and how it could be transmitted. Fifteen $(9.4 \%)$ of the pregnant women claimed to have been vaccinated against rubella, while none of the nonpregnant women had ever received vaccination against rubella (Table 5).

\section{Rubella seroprevalence}

Analysis of the results showed a seroprevalence of $38.8 \%$ (62 of 160) and 93.1\% (149 of 160) for rubella IgM and IgG antibodies, respectively, among the pregnant women, and $40 \%$ (eight of 20) and 90\% (18 of 20) prevalence, respectively, among the nonpregnant women. Of the 149 (93.1\%) pregnant women that were positive for rubella IgG antibody, 59 (39.6\%) were also positive for rubella-specific IgM antibody while out of the remaining 11 (6.9\%) pregnant women that were negative for rubella IgG antibody, 3 (27.3\%) were positive for rubella IgM antibody and the remaining $8(72.7 \%)$ were negative for both $\operatorname{IgM}$ and $\operatorname{IgG}$ antibodies. Among the nonpregnant women, of the 18 (90\%) positive for rubella IgG antibody, seven (38.9\%) were also positive for rubella IgM antibody. Of the remaining two negative for rubella $\operatorname{IgG}$, one was positive and one negative for rubella IgM antibody.

Table I Age distribution of pregnant and nonpregnant women with IgM and IgG antibodies

\begin{tabular}{|c|c|c|c|c|c|c|c|}
\hline \multirow{2}{*}{$\begin{array}{l}\text { Age group, } \\
\text { years }\end{array}$} & \multirow{2}{*}{$\begin{array}{l}\text { Number } \\
\text { analyzed }\end{array}$} & \multicolumn{3}{|c|}{ Rubella IgM } & \multicolumn{3}{|c|}{ Rubella IgG } \\
\hline & & $\begin{array}{l}\text { Number } \\
\text { positive }\end{array}$ & Percentage & $P$-value & $\begin{array}{l}\text { Number } \\
\text { positive }\end{array}$ & Percentage & $P$-value \\
\hline \multicolumn{8}{|c|}{ Pregnant women* } \\
\hline $18-22$ & 23 & 10 & 43.5 & & 20 & 87 & \\
\hline $23-27$ & 52 & 21 & 40.4 & & 47 & 90.4 & \\
\hline $28-32$ & 58 & 22 & 38 & 0.113 & 56 & 96.6 & 0.305 \\
\hline $33-37$ & 21 & 4 & 19 & & 21 & 100 & \\
\hline $38-42$ & 5 & 4 & 80 & & 4 & 80 & \\
\hline $43-47$ & I & I & 100 & & I & 100 & \\
\hline \multicolumn{8}{|c|}{ Nonpregnant women** } \\
\hline $17-19$ & 2 & 2 & 100 & & 2 & 100 & \\
\hline $20-22$ & 7 & 2 & 28.6 & 0.151 & 6 & 85.7 & 0.924 \\
\hline $23-25$ & 10 & 3 & 30 & & 9 & 90 & \\
\hline Above 26 & I & I & 100 & & I & 100 & \\
\hline
\end{tabular}

Notes: *Rubella IgM, $\chi^{2}=8.891, d f=5, P=0.113$; rubella $\lg G, \chi^{2}=6.010, d f=5, P=0.305$; **rubella $\lg M, \chi^{2}=4.549, d f=3, P=0.151$; rubella $\lg G, \chi^{2}=3.333, d f=3, P=0.924$. Abbreviation: Ig, immunoglobulin. 
Table 2 Seroprevalence of rubella IgM and IgG antibodies among pregnant women according to their trimester of pregnancy

\begin{tabular}{|c|c|c|c|c|c|c|c|}
\hline \multirow{2}{*}{$\begin{array}{l}\text { Trimester } \\
\text { of pregnancy }\end{array}$} & \multirow{2}{*}{$\begin{array}{l}\text { Number } \\
\text { analyzed }\end{array}$} & \multicolumn{3}{|c|}{ Rubella IgM } & \multicolumn{3}{|c|}{ Rubella IgG } \\
\hline & & $\begin{array}{l}\text { Number } \\
\text { positive }\end{array}$ & Percentage & $P$-value & $\begin{array}{l}\text { Number } \\
\text { positive }\end{array}$ & Percentage & $P$-value \\
\hline First & 31 & II & 35.5 & & 28 & 90.3 & \\
\hline Second & 82 & 33 & 40.2 & 0.896 & 79 & 96.3 & 0.253 \\
\hline Third & 47 & 18 & 38.3 & & 42 & 89.4 & \\
\hline Total & 160 & 62 & 38.8 & & 149 & 93.1 & \\
\hline
\end{tabular}

Notes: Rubella $\operatorname{lgM}, \chi^{2}=0.220, d f=2, P=0.896$; rubella $\lg G, \chi^{2}=2.745, d f=2, P=0.253$.

Abbreviation: Ig, immunoglobulin.

\section{Risk factors for rubella virus}

Because rubella is predominantly a childhood disease, situations that involve or result in having numerous children around were considered in this study as possible risk factors. Examples include polygamy, occupation type, and place of residence (Table 5). All the possible risk factors considered in this study were, however, not significant. Analysis (IgM and $\mathrm{IgG}$ ) showed that age (pregnant women, $\operatorname{IgM}, \chi^{2}=8.891, d f=5$, $P=0.113$, and $\mathrm{IgG}, \chi^{2}=6.010, d f=5, P=0.305$; nonpregnant women $\operatorname{IgM}, \chi^{2}=4.549, d f=3, P=0.208$, and $\operatorname{IgG}, \chi^{2}=3.333, d f$ $=3, P=0.343)$, trimester of pregnancy $\left(\operatorname{IgM}-\chi^{2}=0.220, d f=2\right.$, $P=0.896$, and $\left.\operatorname{IgG}-\chi^{2}=2.745, d f=2, P=0.253\right)$, reproductive characteristics studied, sociodemographic data gathered, and clinical characteristics observed were not significant risk factors for rubella virus infection for pregnant or nonpregnant women (where applicable), as shown in Tables 1-4 and 6. The level of awareness and knowledge of rubella was very low, despite the fact that the majority of the pregnant women were educated to the tertiary level (Figure 1).

\section{Discussion}

About $93.1 \%$ of the pregnant women had IgG antibodies to rubella virus. This value is similar to the $97.9 \%$ prevalence reported by Mohammed et $\mathrm{al}^{10}$ in Zaria, $96.1 \%$ prevalence

Table 3 Seroprevalence of rubella $\lg M$ and $\lg G$ antibodies among pregnant women according to their reproductive characteristics

\begin{tabular}{|c|c|c|c|c|c|c|c|}
\hline \multirow{2}{*}{$\begin{array}{l}\text { Reproductive } \\
\text { characteristic }\end{array}$} & \multirow{2}{*}{$\begin{array}{l}\text { Number } \\
\text { analyzed }\end{array}$} & \multicolumn{3}{|c|}{ Rubella IgM } & \multicolumn{3}{|c|}{ Rubella IgG } \\
\hline & & $\begin{array}{l}\text { Number } \\
\text { positive }\end{array}$ & Percentage & $P$-value & $\begin{array}{l}\text { Number } \\
\text { positive }\end{array}$ & Percentage & $P$-value \\
\hline \multicolumn{8}{|l|}{ Term deliveries } \\
\hline None & 66 & 24 & 36.4 & & 59 & 89.4 & \\
\hline $\mathrm{I}-4$ & 76 & 29 & 38.2 & & 72 & 94.7 & \\
\hline $5-8$ & 15 & 8 & 53.3 & $0.67 \mathrm{I}$ & 15 & 100 & 0.381 \\
\hline $9-12$ & 3 & 1 & 33.3 & & 3 & 100 & \\
\hline \multicolumn{8}{|c|}{ Preterm deliveries } \\
\hline None & 144 & 56 & 38.9 & 0.914 & 133 & 92.4 & 0.252 \\
\hline $1-4$ & 16 & 6 & 37.5 & & 16 & 100 & \\
\hline \multicolumn{8}{|c|}{ Spontaneous abortions } \\
\hline None & 127 & 48 & 37.8 & 0.627 & 117 & 92.1 & 0.327 \\
\hline $1-4$ & 33 & 14 & 42.4 & & 32 & 97 & \\
\hline \multicolumn{8}{|l|}{ Live births } \\
\hline None & 68 & 26 & 38.2 & & 61 & 89.7 & \\
\hline $1-4$ & 73 & 28 & 42.4 & 0.984 & 69 & 94.5 & 0.413 \\
\hline $5-8$ & 17 & 7 & 41.2 & & 17 & 100 & \\
\hline $9-12$ & 2 & 1 & 50 & & 2 & 100 & \\
\hline \multicolumn{8}{|l|}{ Stillbirths } \\
\hline None & 146 & 55 & 37.7 & & 135 & 92.5 & \\
\hline $\mathrm{I}-4$ & 13 & 7 & 53.8 & 0.377 & 13 & 100 & 0.568 \\
\hline $5-8$ & I & 0 & 0 & & 1 & 100 & \\
\hline \multicolumn{8}{|l|}{ Surviving children } \\
\hline None & 71 & 28 & 39.4 & & 64 & 90.1 & \\
\hline $1-4$ & 75 & 28 & 37.3 & 0.915 & 71 & 94.7 & 0.317 \\
\hline $5-8$ & 14 & 6 & 42.9 & & 14 & 100 & \\
\hline \multicolumn{8}{|c|}{ Malformed children } \\
\hline None & 157 & 62 & 39.5 & 0.164 & 157 & 92.4 & 0.859 \\
\hline $1-4$ & 3 & 0 & 0 & & 3 & 100 & \\
\hline
\end{tabular}

Abbreviation: Ig, immunoglobulin. 
Table 4 Seroprevalence of rubella IgM and IgG antibodies among pregnant women according to their sociodemographic data

\begin{tabular}{|c|c|c|c|c|c|c|c|}
\hline \multirow{2}{*}{$\begin{array}{l}\text { Sociodemographic } \\
\text { data }\end{array}$} & \multirow{2}{*}{$\begin{array}{l}\text { Number } \\
\text { analyzed }\end{array}$} & \multicolumn{3}{|c|}{ Rubella IgM } & \multicolumn{3}{|c|}{ Rubella IgG } \\
\hline & & $\begin{array}{l}\text { Number } \\
\text { positive }\end{array}$ & Percentage & $P$-value & $\begin{array}{l}\text { Number } \\
\text { positive }\end{array}$ & Percentage & $P$-value \\
\hline \multicolumn{8}{|l|}{ Marital status } \\
\hline Married & 158 & 61 & 38.6 & & 147 & 93 & \\
\hline Separated & 1 & 1 & 100 & 0.330 & I & 100 & 0.928 \\
\hline Engaged & 1 & 0 & 0 & & I & 100 & \\
\hline \multicolumn{8}{|l|}{ Educational status } \\
\hline None & II & 6 & 54.5 & & II & 100 & \\
\hline Primary & 6 & 2 & 33.3 & 0.612 & 6 & 100 & 0.601 \\
\hline Secondary & 40 & 17 & 42.5 & & 36 & 90 & \\
\hline Tertiary & 103 & 37 & 36 & & 96 & 93.2 & \\
\hline \multicolumn{8}{|l|}{ Religion } \\
\hline Christianity & 64 & 23 & 36 & $0.55 I$ & 59 & 92.2 & 0.702 \\
\hline Islam & 96 & 39 & 40.6 & & 90 & 93.8 & \\
\hline \multicolumn{8}{|l|}{ Occupation } \\
\hline Student & 59 & 24 & 40.7 & & 55 & 93.2 & \\
\hline Worker & 61 & 22 & 36.1 & 0.859 & 57 & 93.4 & 0.983 \\
\hline Housewife & 40 & 16 & 40 & & 37 & 92.5 & \\
\hline
\end{tabular}

Abbreviation: $\mathrm{lg}$, immunoglobulin.

reported by Tamer et $\mathrm{al}^{18}$ in the western region of Turkey, and $88.6 \%$ prevalence reported by Fokunang et $\mathrm{al}^{19}$ in Cameroon. The high prevalence obtained may have been due to a sustained infection and the development of antibodies to rubella virus. This suggests that rubella virus is prevalent in the study area and that the majority of the pregnant women had previously been exposed to the virus. The figure obtained in this study is, however, much higher than the $53 \%, 7 \%, 68.5 \%, 54.1 \%$, and $76 \%$ reported in other parts of Nigeria by Onakewhor and Chiwuzie, ${ }^{11}$ Agbede et al, ${ }^{12}$ Bamgboye et al, ${ }^{13}$ Bukbuk et al, ${ }^{14}$ and Onyenekwe et $\mathrm{a}^{15}$ in Benin City, Ilorin, Ibadan, Maiduguri, and Lagos, respectively. This indicates that the distribution

Table 5 Seroprevalence of rubella IgM and IgG antibodies among pregnant women according to risk factors

\begin{tabular}{|c|c|c|c|c|c|c|c|}
\hline \multirow[t]{2}{*}{ Risk factors } & \multirow{2}{*}{$\begin{array}{l}\text { Number } \\
\text { analyzed }\end{array}$} & \multicolumn{3}{|c|}{ Rubella IgM } & \multicolumn{3}{|c|}{ Rubella IgG } \\
\hline & & $\begin{array}{l}\text { Number } \\
\text { positive }\end{array}$ & Percentage & $P$-value & $\begin{array}{l}\text { Number } \\
\text { positive }\end{array}$ & Percentage & $P$-value \\
\hline \multicolumn{8}{|l|}{ Marriage type } \\
\hline Polygamous & 34 & 15 & 44.1 & 0.469 & 34 & 100 & 0.074 \\
\hline Monogamous & 126 & 47 & 37.3 & & 115 & 91.3 & \\
\hline \multicolumn{8}{|l|}{ Marriage } \\
\hline First & 145 & 57 & 39.3 & 0.651 & 134 & 92.4 & 0.269 \\
\hline Second or more & 15 & 5 & 33.3 & & 15 & 100 & \\
\hline \multicolumn{8}{|l|}{ Occupation type } \\
\hline Involving children & 78 & 30 & 38.5 & & 71 & 91 & \\
\hline Not involving children & 25 & 9 & 36 & 0.931 & 25 & 100 & 0.304 \\
\hline Unemployed & 57 & 23 & 40.4 & & 53 & 93 & \\
\hline \multicolumn{8}{|l|}{ Husband's occupation } \\
\hline Involving children & 17 & 6 & 35.3 & & 16 & 94.1 & \\
\hline Not involving children & 137 & 53 & 38.7 & 0.816 & 127 & 92.7 & 0.776 \\
\hline Unemployed & 6 & 3 & 50 & & 6 & 100 & \\
\hline \multicolumn{8}{|l|}{ Type of housing } \\
\hline Urban & 129 & 50 & 38.8 & 0.996 & 121 & 93.8 & 0.492 \\
\hline Rural & 31 & 12 & 38.7 & & 28 & 90.3 & \\
\hline \multicolumn{8}{|c|}{ Number of children living in house } \\
\hline None & 62 & 22 & 35.5 & & 57 & 91.9 & \\
\hline Below 5 & 56 & 25 & 44.6 & & 50 & 89.3 & \\
\hline $5-9$ & 28 & II & 39.3 & 0.428 & 28 & 100 & 0.476 \\
\hline $10-14$ & 10 & 3 & 30 & & 10 & 100 & \\
\hline $15-19$ & I & I & 100 & & I & 100 & \\
\hline 20 and above & 3 & 0 & 0 & & 3 & 100 & \\
\hline
\end{tabular}

Abbreviation: $\mathrm{g}$, immunoglobulin. 
Table 6 Seroprevalence of rubella IgM and IgG antibodies among pregnant and nonpregnant women according to clinical symptoms associated with rubella

\begin{tabular}{|c|c|c|c|c|c|c|c|}
\hline \multirow[t]{2}{*}{ Clinical symptoms } & \multirow{2}{*}{$\begin{array}{l}\text { Number } \\
\text { analyzed }\end{array}$} & \multicolumn{3}{|c|}{ Rubella IgM } & \multicolumn{3}{|c|}{ Rubella IgG } \\
\hline & & $\begin{array}{l}\text { Number } \\
\text { positive }\end{array}$ & Percentage & $P$-value & $\begin{array}{l}\text { Number } \\
\text { positive }\end{array}$ & Percentage & $P$-value \\
\hline \multicolumn{8}{|l|}{ Pregnant women } \\
\hline \multicolumn{8}{|l|}{ Mild fever } \\
\hline Yes & 26 & 10 & 38.5 & 0.974 & 25 & 96.2 & 0.505 \\
\hline No & 134 & 52 & 38.8 & & 124 & 92.5 & \\
\hline \multicolumn{8}{|l|}{ Lymphadenopathy } \\
\hline Yes & 0 & 0 & 0 & & 0 & 0 & \\
\hline No & 160 & 62 & 38.8 & & 149 & 93.1 & \\
\hline \multicolumn{8}{|l|}{ Rash } \\
\hline Yes & 5 & 2 & 40 & 0.954 & 5 & 100 & 0.537 \\
\hline No & 155 & 60 & 38.7 & & 144 & 93 & \\
\hline \multicolumn{8}{|l|}{ Headache } \\
\hline Yes & 9 & 3 & 33.3 & 0.731 & 8 & 89 & 0.605 \\
\hline No & $|5|$ & 59 & 39.1 & & $|4|$ & 93.4 & \\
\hline \multicolumn{8}{|l|}{ Arthralgia } \\
\hline Yes & 23 & 7 & 30.4 & 0.376 & 22 & 95.7 & 0.605 \\
\hline No & 137 & 55 & 40.1 & & 127 & 92.7 & \\
\hline \multicolumn{8}{|c|}{ Nonpregnant women } \\
\hline \multicolumn{8}{|l|}{ Mild fever } \\
\hline Yes & 2 & 1 & 50 & 0.761 & 2 & 100 & 0.619 \\
\hline No & 18 & 7 & 38.9 & & 16 & 88.8 & \\
\hline \multicolumn{8}{|l|}{ Lymphadenopathy } \\
\hline Yes & I & 0 & 0 & 0.402 & I & 100 & 0.732 \\
\hline No & 19 & 8 & 42.1 & & 17 & 89.5 & \\
\hline \multicolumn{8}{|l|}{ Rash } \\
\hline Yes & I & 0 & 0 & 0.402 & I & 100 & 0.732 \\
\hline No & 19 & 8 & 42.1 & & 17 & 89.5 & \\
\hline \multicolumn{8}{|l|}{ Headache } \\
\hline Yes & I & 0 & 0 & 0.402 & I & 100 & 0.732 \\
\hline No & 19 & 8 & 42.1 & & 17 & 89.5 & \\
\hline \multicolumn{8}{|l|}{ Arthralgia } \\
\hline Yes & 2 & 1 & 50 & 0.761 & 2 & 100 & 0.619 \\
\hline No & 18 & 7 & 38.9 & & 16 & 88.8 & \\
\hline
\end{tabular}

Abbreviation: Ig, immunoglobulin.

of rubella virus across Nigeria varies for reasons that could possibly be climatic. The development of $\operatorname{IgG}$ antibody is an effort made by the immune system to help neutralize the virus. This antibody prolongs life and confers immunity against reinfection. Therefore, it is correct to assume that the pregnant women that had IgG antibodies are immune.

A clearer picture was, however, seen when the seroprevalence of IgM antibody to rubella virus was also considered. A prevalence of $38.8 \%$ was obtained among the pregnant women for IgM antibody. Significantly, 36.9\% of these pregnant women also had IgG antibody, suggesting either reinfection or resolving primary infection and that they were not actually immune as concluded earlier, but were still in the recovery stage, although this was not confirmed with an avidity test. Most of these women were in their second and third trimesters of pregnancy, suggesting that they were infected earlier in pregnancy, as virtually all infected persons should have developed IgG antibodies by 30 days postinfection. ${ }^{20}$ These pregnant women's fetuses should therefore not be excluded from the risk of CRS. The $38.8 \%$ prevalence obtained is much higher than any that has been reported in Nigeria. Ogbonnaya et al, ${ }^{16}$ Onakewhor and Chiwuzie, ${ }^{11}$ Pennap et al, ${ }^{17}$ and Agbede et al ${ }^{12}$ reported prevalences of $6.8 \%, 10 \%, 4.2 \%$, and $1.1 \%$ in Abia State, Benin City, Makurdi, and Ilorin, respectively.

The high prevalence obtained in the present study suggests the occurrence of an outbreak during the time of the study that might have gone unnoticed, as outbreaks of rubella may not always be recognized in developing countries, such as Nigeria, and rubella-induced rashes are often misdiagnosed. The result goes further to confirm the reported alarmingly increased incidence of rubella in Nigeria between 2009 (234 cases) and 2011 (3,691 cases) by the World Health Organization. ${ }^{21}$ Between 2010 and 2011, there was an eightfold increase in the number of rubella cases from 450 to 3,691 and then a decline in cases, with 239 and 88 cases, respectively, reported in 2012 and 2013. 


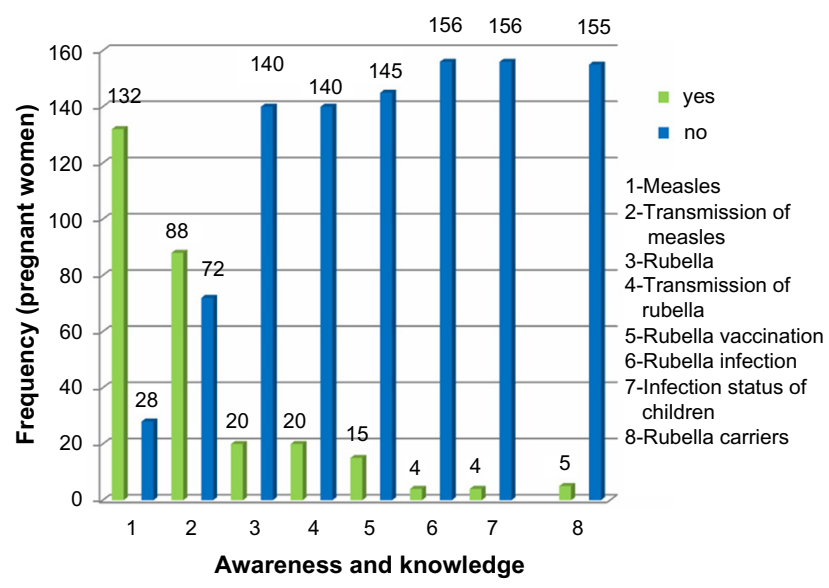

Figure I Frequency of the level of awareness and knowledge of rubella. Note: $1,2, \ldots, 8$ represent different factors or variables as listed beside the figure. For example, I - awareness and knowledge of measles, 2 - awareness and knowledge of transmission of measles, etc. Low and high values can be seen from the frequency (number of pregnant women).

The nonpregnant women also had high prevalence of IgG and IgM antibodies of $90 \%$ and $40 \%$, respectively. The $90 \%$ IgG antibody prevalence is much higher than the $77 \%$ prevalence reported by Onyenekwe et $\mathrm{al}^{17}$ in nonpregnant women in Lagos. However, they observed similar prevalence in pregnant (76\%) and nonpregnant women $(77 \%)$, as also noted in the present study. Seeing as nonpregnant women were involved in the study in order to determine if the risk of infection was higher before or after pregnancy, results showed that risk of infection was high for both groups. This goes a long way to show that although pregnant women are at a greater risk due to fetal infection, attention should not only be placed on them but on the entire population, as they will serve as carriers and a source of infection, which is also a concern. In addition, the higher prevalence of IgM antibody seen in the nonpregnant women further supports the occurrence of an outbreak during the study.

Just as reported by Mohammed et $\mathrm{al},{ }^{10}$ the prevalence of rubella antibodies did not increase with age. This went against many other studies in Nigeria that reported increase with age. This was probably due to the high endemicity of the virus in Zaria, as it is in constant circulation. As such, age and many other factors do not seem to affect the risk of infection. Antibodies were found in all the trimesters of pregnancy, with the highest prevalence being in the second trimester for both antibodies. This agrees with the work of Agbede et al, ${ }^{12}$ but contrasts with the reports of Bamgboye et $\mathrm{al}^{13}$ and Fokunang et al ${ }^{19}$ which showed the highest prevalence in pregnant women in their first trimester. The highest prevalence observed in the second trimester may have been because most of the pregnant women presented at the antenatal clinic in their fourth and fifth months of pregnancy.
The virus is so much in constant circulation that prevalence did not differ much with the reproductive characteristics and sociodemographic data studied. However little, the prevalence of both antibodies was seen to increase with parity and all the other reproductive characteristics studied. Such increased prevalence was also seen in the studies carried out by Bukbuk et al ${ }^{14}$ and Mohammed et al, ${ }^{10}$ which showed increased prevalence with parity, but contrasts with the study carried out by Agbede et al, ${ }^{12}$ which showed a higher prevalence in primigravid women. The reproductive characteristics were not statistically significant with the presence of IgM antibody. No previous study has studied the association between the listed reproductive characteristics and risk of infection. However, Agbede et a ${ }^{12}$ reported that multigravidity was not a predisposing factor to rubella virus infection, with primigravid women showing higher prevalence. The study carried out by Onakewhor and Chiwuzie ${ }^{11}$ also reported higher prevalence in nulliparous women, but in this case with nulliparity being associated with the risk for rubella infection. The result from this study suggests that the reproductive characteristics studied are not significant predisposing factors to rubella infection or immunity.

There was little deviation in prevalence with regard to educational status. Despite the fact that the majority of the pregnant women and all the nonpregnant women were educated up to the tertiary level, the level of awareness and knowledge of rubella and its transmission was very low among the study and control population. This low level of awareness was also seen in the study carried out by Mohammed et $\mathrm{al}^{10}$ in Zaria. This poses a serious problem, as knowledge of a disease and its mode of transmission is important in its prevention and control.

With both antibodies, pregnant women who knew about rubella and how it can be transmitted, the infection status of their children, and the availability of possible carriers around them all had a higher prevalence. This poses a serious problem, as it is obvious that knowledge of rubella and its mode of transmission do not prevent infection. This emphasizes that vaccination is the best means of prevention, and enlightenment without vaccination will achieve nothing.

Of the 15 pregnant women who claimed to have been previously vaccinated, eight were positive for rubella IgM antibody, indicating recent infection. Owing to the fact that women are advised not to become pregnant within 3 months of vaccination, the presence of IgM antibodies in these pregnant women was most probably not due to vaccination, and may have been as a result of the women not knowing exactly what they were vaccinated for and confusing it with rubella 
vaccination, or they simply misunderstood the question. Previous studies mostly consisted of pregnant women who had never been vaccinated. For the control population, who were students of a tertiary institution, none of them had ever been vaccinated; none of them knew their infection status nor did any of them know of possible carriers around them. This is a serious problem, as it is expected that students should be more enlightened, but that was not the case with these women.

None of the characteristics considered to be risk factors was a statistically significant predisposing factor to rubella infection. Some of the common clinical symptoms associated with rubella virus infection were observed in the pregnant women. They included mild fever, rash, headache, and arthralgia (painful joints). None of the pregnant women made complaints of tender, swollen lymph nodes. This is similar to the report by Agbede et al, ${ }^{12}$ who observed that only one pregnant woman complained of swollen lymph nodes. The pregnant women made complaints mostly of fever and aching joints. Very few of these women were, however, positive for rubella infection (IgM antibody), suggesting that the fever and aching joints were due to other factors. This result shows that most of the infected patients were asymptomatic, and none of the clinical symptoms was significantly associated with the risk of infection.

\section{Conclusion}

The prevalence of rubella IgG antibody among pregnant (93.1\%) and nonpregnant women (90\%) was high, suggesting a sustained infection in the population and indicating endemicity. Outbreaks and possibly reinfections are occurring in Zaria, and are going unnoticed due to the absence of clinical symptoms. The fetuses of pregnant women in Zaria are predisposed to CRS due to the presence of $\operatorname{IgM}$ and IgG antibodies. A sustained infection in Zaria makes possible risk factors and clinical symptoms that were studied irrelevant, and the awareness level of rubella virus and the infection it causes is very low.

\section{Recommendations}

It is essential for a national rubella vaccination program to be initiated in Nigeria. US recommendations are for childhood vaccination to prevent epidemics, combined with the vaccination of susceptible nonpregnant adolescent and adult females. ${ }^{11}$ Pregnant women and women attending preconception programs should be screened for rubella, and postpartum vaccination should be done for seronegative women.

The low level of awareness emphasizes the need for women to be enlightened about rubella infection, its dangers, and how it can be prevented. As such, rubella should be included in the health talks given to pregnant women in antenatal education programs and women in preconception programs. Measures should be taken to ensure that outbreaks do not go unnoticed and are eventually stopped to prevent the free reign of rubella virus.

Finally, pregnant women should be advised to seek antenatal care earlier. This way, pregnancy can be more accurately monitored. Also congenital anomalies and their risk burdens can be better assessed and arrested in good time.

\section{Limitations of the study}

During the study, many of the pregnant women presented at the antenatal clinic in the second trimester (about 5 months), making it difficult to adequately assess the risk burdens associated with infection with rubella virus. Also, the majority of the pregnant women did not want to take part in the study, saying it was not necessary and they did not need it. This made sample collection very difficult and was discouraging.

\section{Acknowledgments}

The authors are grateful to the Department of Microbiology, Faculty of Science, Ahmadu Bello University and the entire staff of the Obstetrics and Gynaecology Department, Ahmadu Bello University Teaching Hospital, for their contribution to the study. This work was carried out in the World Bank/Federal Government of Nigeria sponsored Science and Technology Education Post-Basic (Step-B) Projects Laboratory housed in the Department of Microbiology, Faculty of Science, Ahmadu Bello University, Zaria, Nigeria.

\section{Disclosure}

The authors report no conflicts of interest in this work.

\section{References}

1. Mayo Clinic. Diseases and conditions: rubella - prevention. 2011. Available from: http://www.mayoclinic.com/health/rubella/DS00332/ DSECTION=prevention. Accessed March 30, 2012.

2. Willey J, Sherwood L, Woolverton C. Human diseases caused by viruses and prions. In: Prescott's Microbiology. 8th ed. New York: McGraw-Hill; 2011:905-906.

3. Brooks GF, Carroll KC, Butel JN, Morse SA, Mietzer TA. Rubella (German Measles) Virus. In: Jawetz, Melnick, and Adelberg's Medical Microbiology. 26th ed. McGraw-Hill Lange Companies U.S.A; 2013: 607-612.

4. Hesketh LM. Togavirus: Rubella. In: Greenwood D, Barer M, Slack R, Irving W edited Medical Microbiology, A guide to Medical Infections: Pathogenesis, Immunity, Laboratory Investigations and Control. 18th ed. Churchill, Livingstone, Elsevier, Edinburgh; 2012: 602-606.

5. Kimberlin WD. Rubella virus. In: Richman DD, Whitley JR, Hayden GF, editors. Clinical Virology. 2nd ed. Washington: American Society for Microbiology; 2002;1211-1226.

6. Haaheim LR, Pattison JR, Whitley RJ, editors. A Practical Guide to Clinical Virology. 2nd ed. Hoboken (NJ): John Wiley and Sons; 2002. 
7. World Health Organization. Rubella: fact sheet 367. 2012. Available from: http://www.who.int/mediacentre/factsheets/fs367/en. Accessed June 26, 2014.

8. Brooks FG, Carroll CK, Butel SJ, Morse AS. Jawetz, Melnick and Adelberg's Medical Microbiology. 24th ed. New York: McGraw-Hill; 2007.

9. Lombardo PC. Dermatological manifestations of rubella. Available from: http://emedicine.medscape.com/article/1133108-overview. 2011 Accessed March 22, 2012.

10. Mohammed DA, Shittu O, Sadauki H, Olayinka A, Kolawole B, Adejo D. Prevalence of rubella IgG antibodies among pregnant women in Zaria, Nigeria. Int Health. 2010;2(2):156-159.

11. Onakewhor JU, Chiwuzie J. Seroprevalence survey of rubella infection in pregnancy at the University of Benin Teaching Hospital, Benin City, Nigeria. Niger J Clin Pract. 2011;14(2):140-145.

12. Agbede OO, Adeyemi OO, Olatinwo AW, Salisu TJ, Kolawole OM. Seroprevalence of antenatal rubella in University of Ibadan Teaching Hospital. Open Public Health J. 2011;4:10-16.

13. Bamgboye AE, Afolabi KA, Esumeh FI, Enweani IB. Prevalence of rubella antibody in pregnant women in Ibadan, Nigeria. West Afr J Med. 2004;23(3):245-248.

14. Bukbuk DN, el Nafaty AU, Obed JY. Prevalence of rubella-specific IgG antibody in non-immunized pregnant women in Maiduguri, north eastern Nigeria. Cent Eur J Public Health. 2002;10(1-2):21-23.
15. Onyenekwe CC, Kehinde-Abgeyangi TA, Ofor US, Arinola OG Prevalence of rubella-IgG antibody in women of childbearing age in Lagos, Nigeria. West Afr J Med. 2000;19(1):23-26.

16. Ogbonnaya EC, Chinedu EK, John A, Esther A. Survey of the seroprevalence of $\operatorname{IgM}$ antibodies in pregnant women infected with rubella virus. J Biotech Pharm Res. 2012;3(1):10-14.

17. Pennap G, Amauche G, Ajoge H, Gabadi S, Agwale S, Forbi J. Serologic survey of specific rubella virus $\operatorname{IgM}$ in the sera of pregnant women in Makurdi, Benue State, Nigeria. Afr J Reprod Health. 2009;13(2): 69-73.

18. Tamer GS, Dundar D, Caliskan E. Seroprevalence of Toxoplasma gondii, rubella and cytomegalovirus among pregnant women in western region of Turkey. Clin Invest Med. 2008;32(1):E43-E47.

19. Fokunang CN, Chia J, Ndumbe P, Mbu P, Atashili J. Clinical studies on seroprevalence of rubella virus in pregnant women of Cameroon regions. Afr J Clin Exp Microbiol. 2010;11(2):79-94.

20. ClinLab Navigator. Rubella. 2013. Available from: http://www. clinlabnavigator.com/rubella.html. Accessed February 11, 2013.

21. World Health Organization. WHO vaccine-preventable diseases: monitoring system. 2014 global summary. 2014. Available from: http:// apps.who.int/immunization_monitoring/globalsummary/countries?cou ntrycriteria[country][]=NGA. Accessed June 25, 2014.
International Journal of Women's Health

\section{Publish your work in this journal}

The International Journal of Women's Health is an international, peerreviewed open-access journal publishing original research, reports, editorials, reviews and commentaries on all aspects of women's healthcare including gynecology, obstetrics, and breast cancer. The manuscript management system is completely online and includes

\section{Dovepress}

a very quick and fair peer-review system, which is all easy to use. Visit http://www.dovepress.com/testimonials.php to read real quotes from published authors. 